\title{
World Bank Education Sector: From Internal and External Perspectives
}

Kye Woo Lee* Ahreum Han ${ }^{* *}$

\section{Abstract}

This paper describes the authors' almost 30-year (1972-1998) personal experience with the World Bank (WB) education sector operations from the internal perspective. Then, it discusses the authors' 20-year (1999-2020) observation from an external perspective. The paper aims to reveal the goals, objectives, strategies, the mechanism, and processes of decision-making, especially on how an education loan and credit is justified, of the world's largest international aid organization for the education sector in developing countries (some $\$ 4$ billion a year). Through this effort, the author provides a sound basis for insiders' and outsiders' fair assessments or criticisms of WB

\footnotetext{
* Main author: Former Professor, KDI School of Public Policy and Management / kyewoo@hotmail.com

*** Co-Author: Assistant Professor, Trinity University / ahan1@trinity.edu

(c) Copyright Korea International Cooperation Agency. This is an Open-Access article distributed under the terms of the Creative Commons Attribution Non-Commercial License (http://creativecommons.org/ licenses/by-nc/4.0/) which permits unrestricted non-commercial use, distribution, and reproduction in any medium, provided the original work is properly cited.
} 
education sector operations. It also allows for some lessons/suggestions for the future WB education sector operations and for possible participations, collaborations, and cooperation with outsiders interested in WB operations in the education sector.

Key words: World Bank, Education Sector, Personal Experience, Lessons Learned 


\section{I . INTRODUCTION}

This paper describes one of the authors' almost 30-year (1972-1998) personal experience with the World Bank (WB) education sector operations from the internal perspective, followed by authors' 20-year (1999-2020) observation of them from an external perspective. The paper aims to reveal the goals, objectives, strategies, the mechanism and processes of decision-makings, especially how an education loan and credit is justified, of the world largest international aid organization for the education sector in developing countries (some $\$ 4$ billion a year). Through this effort, the authors try to provide a sound basis for insiders' and outsiders' fair assessments or criticisms of WB education sector operations and draw some lessons/suggestions for the future WB education sector operations and for possible participations, collaborations and cooperation of outsiders interested in WB operations in the education sector.

\section{FROM INTERNAL PERSPECTIVE- 1960s - 1990s}

The most challenging task I had ever experienced with the WB education sector was how to justify the projects that I had to assess as a member of the WB appraisal teams. Of course, I had to follow Bank education sector operations policy. However, a written Bank education sector policy was often unavailable for quite some time (the first official policy was published in 1974) or not updated in a timely fashion. Other times, it was available, but too general and lacked guidance for a specific country and time (Pacharopoulos, 2006; 〈Table 1〉).

Before I joined the WB, I had assumed Bank education sector operations would be dictated by the philosophy or theory of the education sector. Therefore, as an economist, I felt uneasy and anxious when I joined the Bank's education sector operations in September 1972. However, no education sector policy existed then in the Bank. My experience shows that de facto Bank education sector operational strategy was dictated to a great extent by the Bank-wide operations strategy on the one hand, and the prevailing development economics theory on the other. The formal Bank education sector policies or strategies did 
〈Table 1〉 History of education sector operational policies of the World Bank

\begin{tabular}{c|c|c}
\hline Year & Document & Remarks \\
\hline 1945 & Bank operations start & \\
\hline 1963 & First Education loan & \\
\hline 1967 & Prof. Blaug's White Paper & $\begin{array}{c}\text { Recommends the rate of return approach to } \\
\text { justify Bank education lending projects }\end{array}$ \\
\hline 1970 & $\begin{array}{r}\text { President's second memo on } \\
\text { education policy }\end{array}$ & \\
\hline 1972 & Education Sector Policy Statement & policy and programs \\
\hline 1974 & $\begin{array}{c}\text { Education Sector Working Paper } \\
\text { Includes Bank education sector lending }\end{array}$ \\
\hline 1990 & Primary education policy paper & \\
\hline 1999 & VoCED policy paper & \\
\hline
\end{tabular}

Source: Pasacharopoulos G. (2006); World Bank (1974).

not provide much guidance on the appraisal or justification of the project proposed by the government. Incidentally, the Bank-wide operational strategy and the development economics theory evolved over time about every decade. Therefore, my experience with the Bank education sector operations was a history of the evolution of Bank-wide operational strategy and development economics theory.

In my opinion, the education sector operations made decent contributions to the achievement of the development goals and objectives of the WB since the 1960s through expansion of educational opportunities for school-age children and youth, and improvement of academic achievements of students (Heyneman \& Lee, 2016). During the next 15 to 20 years, the Bank-wide operational strategy will again have to be adjusted to the UN's Sustainable Development Goals (SDGs), and accordingly, education sector operational strategies will have to be updated as well.

\section{During the 1960s: Economic Growth}

When I met the supervisor of my new job in September 1972, I was told that 
after five days (including the Labor Day holiday), I was scheduled for a business trip to a country in Central America for about four weeks, together with a team of 5 professionals. The Bank called it an appraisal mission to assess an education project proposed by the government for Bank financing. My supervisor emphasized that this mission was the most critical stage of a project cycle since it would have to justify the proposed loan to the Board of Directors, and it would be the final step of the technical justification process. I was given a pamphlet on the project cycle, a reference document on the educational development history in Europe and the Western Hemisphere, and a sample appraisal report of the past operation. However, there was no education sector policy or strategy paper. Instead, I was told that another education economist, who had joined the Bank a year ahead of me after several years' experience at the Asian Development Bank, would travel with me to provide field guidance and assistance for the first five days.

Upon arrival in the country, my tutor and I had to work with an interpreter provided by the Ministry of Education (MOE) since three out of the six mission members totally lacked Spanish proficiency. Such mission composition in terms of language proficiency was apparently standard for the Bank at that time since the Education Sector Department (ESD) of the Bank was centralized and organizationally separated from the decentralized Country Program Department of the Regional Vice-Presidencies. The rationale for the ESD's centralized organization like all other sector departments was cross-fertilization of better sector policies and practices among regions. Since sector staff members were supposed to work across the regions, they did not have in-depth knowledge about specific countries. Therefore, I appreciated that my tutor made an arrangement for a briefing on the country by the Program Department's country economist and loan officer before our departure for the country. They also provided us the latest country economic report, which proved extremely useful for my mission task.

The project proposed by the government had two components. One was to expand and improve the general secondary education program, and the other one was to expand and strengthen the National Apprenticeship Institute, which had been established just a couple of years before and managed institutionalized 
non-formal vocational and technical training programs across the country. The mission's main task was to justify the two project components from economic and social points of view and ensure the technical aspects of the two components were sound. I realized that my main mission role was to assess the link and consistency between the national economic and social development strategy and the proposed project.

Technically speaking, it was not onerous, since I had been in charge of analyzing the vocational and technical manpower requirements for the Second Five-Year Economic Development Plan of Korea (1967-71) when I was working at the middle management level for the Korean government. I asked MOE for an analysis of the national vocational/technical manpower requirements by industry, occupation, level of education and year of working experience. The MOE's response was that it had done such an analysis a few years ago, and that it would need to be updated by the end of our mission's stay in the country. In the meantime, I started collecting necessary data and parameters for such an analysis. However, I could not get the updated analysis from MOE until the final day of the mission, and MOE finally promised to send it to the WB in Washington, DC, by express mail the next week; it was actually never received by me despite several phone calls I placed. It was a cultural shock to me.

As soon as we came back from the Central American mission, I was assigned to the ESD of the East Africa Regional Vice-Presidency. I wrote my portion of the appraisal report and submitted it to the mission leader in the ESD of Latin America and the Caribbean Regional Vice-Presidency. While we were on mission, the Bank underwent a drastic organizational change under the direction of the President, Robert McNamara. He decentralized all sector departments to each of the six regional vice presidencies, so that country and sector departments could work more closely under a single vice president. Sector department professionals were meant to become more specialized in one region, so they could respond to regional demands more quickly and appropriately.

Upon returning to the Bank headquarters, I had to prepare the analysis of manpower requirements by myself without consulting with the borrowing country government officials. However, my analysis and write-up must have struck my supervisors well since, instead of the mission leader, I was asked to 
be responsible for preparing the whole appraisal report based on the contributions from the mission members, and later for presenting the project to the Board of Directors for approval. Therefore, two weeks after I was assigned to the East Africa Regional Vice-Presidency, I was called back to the Latin America Regional Vice-Presidency. Other colleagues envied my situation since most new staff members were able to lead a mission only after some years of Bank experience. However, I had to sweat a lot to learn the Bank report writing skills in a leap frog way.

Before I joined the Bank in 1972, the Bank-wide operational objective had been economic development, especially economic growth, of member countries, and the main means for the Bank to achieve such a goal was lending operations for the infrastructure sectors. I thought the theoretical basis for the Banks's disproportionally heavy infrastructure lending at that time was Harrod-Domar Growth Theory (Domar, 1946; Harrod, 1939), which stated that economic growth was attainable exclusively through investment in and accumulation of physical capital. In the 1960s, therefore, the education sector in the WB was at an embryonic stage, and tried to prove its ability to contribute to the Bank-wide objective of economic development, in particular economic growth. Therefore, with the assistance of UNESCO's technical cooperation team, the education sector selected for its initial lending operations institutionalized, non-formal vocational training projects and general secondary education, especially in Latin America, and engineering and technical higher education projects in Asia. Such operations were justified by the manpower requirements for economic growth and was also supported by the inventive theory of human capital contributions to economic growth, as outlined by Becker (1964) and Schultz (1961). The theory and practices of the education sector operations did not have much gaps at all in terms of their rationale and justification.

However, I felt that there was doubt in the Bank on whether education sector operations had a proper role, since the Bank's main objective was economic growth of member countries exclusively by physical capital investment. The education sector operations were therefore regarded as extraneous. To allay such doubts, a cautiously formulated strategy of the education sector operations was to emphasize building construction and equipment and furniture provision 
for vocational and engineering education and training (what was called hardware inputs), as well as transform general secondary education to more practical secondary education programs. I thought this strategy was consistent not only with the Bank-wide operational objective and strategy, but also with the theory of human capital contributions to economic growth. UN agencies' operations in the education sector were limited to technical assistance and social relief operations, and therefore, Bank lending operations in the education sector did not pose any threat or competition.

\section{During the 1970s: Steady Goal, Strategic Shift to Poverty} Alleviation

The Bank-wide operational goal of economic growth of developing countries was maintained in the 1970s as in the 1960s; however, the means for achieving it was radically changing by emphasizing poverty eradication, especially in the rural and farming sectors. McNamara's address at the World Bank-IMF Annual Meeting in Nairobi, Kenya (1973) eloquently laid out the strategy and its rationale. It gave me a strong impression that the development economics was sharply shifting its emphasis from growth theory to welfare economics theory. The theory of the second best by Lipsey \& Lancaster (1956) seemed to support the Bank's strategic shift. Despite the large amount of aid in the earlier decades, the market failures in the infrastructure-industrial-urban sectors did not improve people's living standards in aid-recipient countries; rather, poverty in the ruralagricultural sectors persisted or got worse. Therefore, governments would intervene contrary to usual policy and invest in the rural and agricultural sectors directly to attack poverty.

The Bank quickly expanded agricultural sector operations, transforming them to integrated development operations covering agricultural production, extension, livestock, and irrigation components, and to rural and regional development operations including roads, water, education, population, health, tourism, and small-scale manufacturing sectors. The Central Projects Vice-Presidency monitored each regional lending operation's contributions to poverty alleviation by measuring the proportion of the poor among the project's targeted beneficiaries. 
Although these integrated agricultural and regional development projects contributed to the rapid expansion of WB lending amounts, the pace of the rural poverty reduction was not so rapid during McNamara era. Therefore, the WB received a fair amount of criticism, especially by the USA Congress during IDA replenishment approval period. A lot of Bank staff thought that the "integrated planning" was a good idea, but the "integrated or coordinated execution" was not realistic and feasible in developing countries. If they can do it well, they would be no longer developing countries.

The education sector operations also spread their scope to other levels of education, especially non-formal education for adults or farmers and basic education in rural areas. They did not need to be justified by the manpower requirements for economic growth. As long as the target groups of the education sector operations were poor, especially in rural areas, free-standing education sector operations and the education and training components of regional development and integrated agricultural development operations, could be justified based on the poverty alleviation and the theory of human capital contributions to growth. The education sector was no longer extraneous; from the marginal areas it slowly approached toward the center of Bank operations based on the human capital theory and its contributions to poverty alleviation. In the 1970s, the size of the education sector lending almost doubled in every five years. It would have been difficult for the education sector to expand its lending operations by formulating an education sector strategy based mainly on education sector philosophy or theory. The sheer expansion of the education sector lending was a part of the much larger trend of overall Bank-wide lending operations, which increased about 400\% in the 1970s under McNamara's presidency.

In addition, other sectors, like agriculture, water supply, and transport, sought education sector advice and assistance for preparation and appraisal of their project-related training. As a result, the Sector Department Director of the LAC Region appointed me as an informal coordinator of project-related training programs in addition to my formal title of Deputy Division Chief of the Education Sector. This informal title provided me an excellent opportunity to learn how the other sectors in the Bank operated. I had felt Bank careers were 
too narrowly specialized by sector and rarely provided an opportunity to gain experience across sectors. This experience with projects-related training provided a good springboard to get promoted when the Central Projects Vice- Presidency announced an opening for the projects policy adviser's position, which directly supports the Vice President's function as one of the three Bank-wide Loan Committee members. This Committee was to review and approve project loan proposals of all sectors of each Regional Vice-Presidency before they could start loan negotiations with the borrowing country's delegation.

In the 1970s, there was another transformation in the Bank, this time in the education sector operations. Almost all Latin American countries were incited by the Bank to transform theoretical secondary schools into practical secondary schools, so that students were to be exposed to industrial, business, and home management technical skills education and training in addition to the traditional general curricula. The comprehensive secondary school concept was apparently influenced by the multilateral secondary school concept, which was fashionable in the United Kingdom under the Labour Party's education policy. The policy concept was matching the Bank's de facto education policy of satisfying the manpower requirements of the industrial development policies of many developing countries at that time. Many countries in Latin America took advantage of this Bank education policy to expand secondary education opportunities at high cost. These schools were all constructed with industrial workshops and laboratories filled with costly equipment, furniture and educational materials for the initial few years. However, a large portion of the graduates continued with higher education, and some graduates who entered the labor market did not satisfy employers' expectations in terms of skill levels.

In addition, negative evaluation and research results of vocational/technical education and training programs reinforced inside and outside criticisms of the Bank's education and training policy, which was based on manpower requirements. The factors responsible for such disappointments were numerous. Most important in my opinion were much slower economic growth rates than those assumed for the manpower requirement analysis, due especially to the two oil crises in the 1970s; insufficient teaching/training materials; and insufficient education/training programs for the practical subject teachers who used the work- 
shops and laboratories; as well as socio-economic prejudices toward vocationaltechnical track graduates entering the labor market instead of proceeding to higher educational institutions.

Therefore, in the late 1970s, some innovative staff members tried to apply economic cost-benefit analysis to justify appraised projects, although, unlike all other sectors of the WB, the education sector was formally waived for carrying out such analysis. One project, praised by the Board for taking such an approach, treated the sum of annual school building rental costs saved as project benefits and the construction costs of new secondary schools as project costs, thereby computing a rate of return and cost-benefit ratio. However, I felt that the appraisal team was misusing the cost-benefit framework. The benefit and cost should be defined from the project objective. For such an education project which aimed to improve the quality of learning, a cost-effectiveness analysis should have been adopted by treating students' enhanced academic achievements in the new school buildings as project benefits, and the construction and operating costs of the new school buildings as costs, and this ratio should have been compared with the ratio between the academic achievements and rental and operational costs of current school buildings. As such, a cost-effective analysis instead of a rate of return or cost-benefit ratio analysis would have been more appropriate framework as an economic analysis of the project.

\section{During the 1980s: Debt Resolution}

In the 1980s, the Bank's mandate for poverty alleviation had to be interrupted. The world's economies, especially in Latin America, were in deep recession due mainly to the 1980s debt crises. The actual growth rate over the 1980s was negative; hence a lost decade. With a realistic projection of negative growth rates, the manpower requirement approach to justifying education/training projects did not have much room to maneuver. Development Economics such as human capital or welfare theory also lacked room to play. From that point, neo-classical economics dictated the Bank's country assistance strategies. The debt crises were caused by excessive borrowing by the government and state-owned enterprises during and after the oil crises in the 1970s, the easy 
access to international financing sources, as well as the sudden and sharp increases in interest rates to arrest galloping inflation. The public sector was forced to adopt retrenchment and liberalize economies, including trade, finance, housing, and labor markets.

The size of Bank lending for the education sector did not increase much and stagnated during the 1980s. This was not the result of the Bank's active education sector policy; the education sector was forced by the Bank-wide lending operational strategy. In the 1970s, under McNamara's presidency, the Bank lending level increased by some $400 \%$, but in the 1980 s, it rose only by $10 \%$. Bank lending emphasized fiscal sector retrenchment and economic structural reform in its member countries. The Bank and IMF did not select a specific sector for reducing public expenditures, but many developing countries selected social sectors to comply with retrenchment prerequisites for structural adjustment loans, and the education sector bore the brunt of the cuts. Within the education sector, for political convenience, basic education took the shock most severely in Latin America. By this time, Bank education sector policy encouraged member countries to prioritize basic education investment, since research outside the Bank showed that the rate of return for primary education was higher than that for secondary and higher education (Psacharopoulos, 1985). However, the negative effects of the structural reform program on the social sectors, particularly education, were so severe that other international aid agencies, particularly UNICEF, criticized the Bank-wide lending strategy as "structural reform without human face." The Bank education sector maintained the traditional fields of lending: general secondary education and basic education, diminishing technical education, but adding higher education, despite its advice for its member countries against this level of education in terms of investment priority.

\section{During the 1990s: Poverty Reduction Again and Growth Recovery}

In 1987, with the appointment of the new president, Barber Conable, the WB went into another reorganization, which reinforced the decentralization and regionalization of the earlier reorganization in 1972. The essence of this 
reorganization was, first, dividing the country program department of each Regional Vice-Presidency to deepen the relations with client countries. Each country program department would be responsible for a group of countries in the same Regional Vice-Presidency, and the sector department of the Regional Vice-Presidency, which was already regionalized in 1972, would be divided and downgraded to belong to each of the several country programs departments. Second, the Regional Vice-Presidency would become more autonomous in approving loans/credits; in addition, a new technical department would advise and monitor the operational quality of the sector divisions of various country program departments based on its own research and policy work. Therefore, this reorganization implied proliferation of a large number of positions for technical specialists and middle-level managers. With this reorganization, I was transferred from the Central Projects Vice-Presidency to the Mexico and Central America Country Department, which also covered Venezuela later, as a Projects Policy Adviser.

In the early 1990s, all Bank staff members were called to a meeting to be briefed by senior officials on another reorganization. The main message was that the Bank would create another Regional Vice-Presidency called Eastern Europe and Central Asia, and a lot of resources would be channeled from the existing Regional Vice-Presidencies to this new one. In 1989, the East German government collapsed, and in 1991, the Soviet Union was dissolved, and its satellite countries all became independent. The Cold War, which was one of the main causes of the birth of the WB and IMF, ended, and the Bank gained the chance to help transform the former planned economies to market-oriented ones, assist in creating new political and economic systems and institutions, alleviate poverty in developing countries, and help their economies recover from the recession of the 1980s. I felt that these new Bank mandates were based on the theories of institutional economics, welfare economics, and human capital economics.

To implement these new mandates, the education sector renewed its effort to promote vocational-technical education for economic growth, which had been somewhat neglected during the previous decade, and basic education for poverty alleviation. The Bank education sector published policy papers on voca- 
tional-technical education and basic education (World Bank, 1990, 1991, respectively). The vocational-technical education policy paper preferred not diversified or comprehensive secondary education programs, but separate and specialized vocational and technical secondary schools or programs. The basic education sector policy emphasized a higher rate of return to basic education than secondary and higher education, but did not impose an exclusive investment in basic education before investment in secondary or higher education.

\section{1) Application of the mandates in Mexico}

However, since the 1987 reorganization, human development lending operations in our department were in trouble. In the first place, our Mexico and Central America country department was the only country department out of some 30 in the Bank that lacked a human development sector division. The human development sector was to be responsible for education, health and population, and social protection subsectors.

The main reason for this absence was that the government of Mexico did not want to borrow from abroad for the human development, in particular education, sector. Mexico's constitution allows borrowing from abroad only for "productive sectors," and the government officials argued that the human development sector had not been defined as productive for a long time. This clause was apparently based on Mexico's history of repeated foreign debt defaults and invasions by foreign military forces. Because of Mexico's position, our department could not meet the demand for Bank lending for countries in Central America that saw human development investment as productive. The absence of human development sector operations was a great disadvantage for poverty-oriented lending operations. With the support of the Vice-President, therefore, our department rushed to create a human development sector division at the beginning of the 1990s. Because of my past experience with human development sector management, I was asked to create and head it.

Since the human development sector division was created in the middle of a fiscal year, the budget provided was small compared with those for other sector divisions. Moreover, the division budget composition was a great disadvantage, allocating most funds for hiring consultants; only some 30\% of the total budget 
was from a regular source. This was exactly the reverse ratio of other sector divisions' budgets. Therefore, with only a few regular (permanent) staff members, we had to play the main role for meeting the new poverty-oriented lending mandate. Fortunately, I was able to assemble a small number of energetic, dedicated, and talented staff members in a relatively short time.

Moreover, we were able to use our budgetary disadvantage as a positive tool. At the time, to support the new Bank mandates, several advanced countries began to contribute their financial resources as trust funds to the WB, and most were exclusively earmarked for project-preparation purposes. Among these trust funds, the PHRD Fund donated by the government of Japan was the largest (about $\$ 1$ billion) and prioritized human development sector operations. Therefore, as soon as we identified project proposals from our client countries, our staff started preparing trust fund applications to make up for our small regular budget. Even after our budget composition issue was redressed and endowed with a similar ratio as other sector divisions in the following year, our staff continued preparing trust fund applications competitively, partly because they were motivated by my delegating them the execution of the approved trust funds. About three or four years later, the size of our sector division budget was the largest in our department, and the number of staff members and size of lending operations were the largest among Bank-wide education sector divisions.

A unique exception to the Mexico government's policy for non-borrowing from the Bank was the vocational-technical education and training programs, since they provided the skilled and technical manpower needed by the directly productive sectors for national economic growth. At the request of the Mexican government, the Bank has financed a technical secondary education program since the late 1970s. A group of reform-minded senators in Mexico pushed the government to launch vocational-technical secondary education in earlier years. Industrializing Mexico desperately demanded vocational-technical skills, but the vocational-technical secondary education program was so dysfunctional and of poor quality that it did not meet industrial and youth demands. Because the strong teachers union adamantly opposed any reform, the government created a semi-autonomous organization called CONALEP (National College of Professional Technical Education). This college tried to establish and operate a 
national network of technical secondary schools with only contracted instructors seconded by nearby private and public enterprises, so instructors could not organize a school-based trade union.

With the Bank's three-time repeat financing, these schools were operating exceedingly well. Most graduates were employed immediately at relatively high wage rates, as expected at appraisal. However, these positive results were confirmed only by Bank supervision visits to enterprises and CONALEP's superficial opinion surveys of graduates and employers, but never by rigorous and scientific tracer studies of the graduates, which was a covenant of the Bank loan agreement. CONALEP did not feel it was necessary since they could confirm the graduates' placement situation by visits and feedback from graduates and employers. The previous Bank officer and manager in charge of the project's supervision accepted those opinion surveys as complying with the special covenant.

As our department was about to negotiate for the proposed fourth and final lending operation for the improvement and expansion of CONALEP in 1991, our technical department advisers criticized the lack of rigorous and scientific tracer studies. They advised that the negotiation should be delayed until such studies were completed and reviewed by the Bank.

However, delayed project negotiations of this first operation of the new sector division would create serious troubles for meeting Departmental operational targets and the reputation of this newly created sector division. As a new manager of the sector division, I offered a compromise. The loan agreement for the new and final operation would include the same covenant again, and a rigorous and scientific tracer study would be completed to our satisfaction. The compromise was agreed on, and we were able to meet the operational targets. However, during the next four years we had a hard time persuading CONALEP to carry out such rigorous tracer studies. Once I jokingly suggested to the Director General of CONALEP that if they completed rigorous tracer studies, I would use the data to contribute an article to a world renowned education sector journal to publicize CONALEP's performance and achievements. In the end, CONALEP completed a two-year tracer studies, and as promised, I wrote a paper on the evolution of vocational and technical secondary education in Mexico that was published in an education sector journal (Lee, 1998). 
A few years later, I retired from the Bank and repatriated to my home country to teach at a graduate school. One day, I received an international mail in a mutilated envelope, which had been sent to the WB in the USA and then forwarded to Seoul, Korea. It was from the former CONALEP Director-General, who thanked me personally for the article, and then said that thanks to it, he got a promotion to the presidency of one of the most prestigious universities in Mexico, from which the incumbent president of Mexico graduated.

This MOE technical training project loan was followed by two more vocational-technical training project loans for the Ministry of Labor's (MOL's) implementation for economic growth in 1992 and for both MOL's and MOE's implementation in 1994.

Finally, to address the poverty problems in Mexico, we felt that basic education and health issues, especially in the rural areas, should be dealt with. However, because of the government position against borrowing for non-productive sectors and our ignorance of the sectors in depth, we were stumped. In the end, our policy dialogue with senior policy makers of the MOE reached an agreement that the Bank staff would make a sector study to investigate sectoral issues/ problems and propose strategies and priority action programs without the government's commitment to borrowing from the Bank.

The MOE policy makers were so impressed by the report's clear and sharp analysis that the Vice-Minister invited us to have a one-day seminar at a closed meeting with the senior officials of the MOE. This report and seminar softened MOE's suspicion of Bank's technical assistance capacity and its position of not borrowing from the Bank for education sector. In addition, we argued that the Ministry of Health and Social Services (MOH) collaborated with our human development sector division for a basic health care loan in early 1990, and the health care and education services are two important parts of investment in human development; MOE would also benefit from collaboration with the Bank.

In 1991 and 1992, the Bank and government of Mexico finally launched two projects to address the priority needs of the poverty groups, which were identified by the earlier Bank sector studies: primary education in four poor and underserved states and initial (early childhood) education in ten poor states on a pilot basis out of a total 32 states. The primary education project aimed to: 
(i) provide educational materials, including books for school libraries and some bilingual reading books for primary schools mostly in rural areas; (ii) upgrade skills of underqualified teachers and provide in-service training for qualified teachers and teacher trainers; (iii) rehabilitate, replace and construct educational facilities; and (iv) strengthen the institutional capacity for improving the supervision system, support service delivery system, and the information, monitoring and evaluation systems, including selected studies to assess the impact of project activities.

The initial (early childhood) education (IE) project aimed to: (i) develop and upgrade human resources in the IE subsector; (ii) develop and distribute instructional materials for IE, and (iii) strengthen management capacity at federal, state, and community levels. This project supported the Mexican government's innovative strategy to redress the inequity in opportunity and quality of primary education, and the health and nutritional status of children before entering kindergarten and primary schools by educating and training parents in early childhood development in the poor, rural and lagging areas. Although this free-standing project was the first lending operation of its kind in the Bank, and the official Bank policy paper did not have any formal policy statement on this level of education, we did not encounter any problems in financing it. Rather, we were praised at the Board presentation for taking this initiative for poverty reduction. Also, the government of Belgium joined the WB in financing this innovative project.

Also in 1992, the Bank agreed to lend for MOL's implementation of a largescale vocational-technical retraining program and labor mobility improvement program addressing the massive unemployment of displaced workers during the debt crisis in the 1980s and labor market mobility and employment services problems for rapid economic growth recovery.

The next two years were a slack period for our sector operations, partly because both the Bank and the government wanted to observe how the initial pilot projects took off for implementation, and partly because the MOE's enthusiasm lapsed somewhat. In 1994, however, the Bank and the Mexico government agreed to launch two more operations: Primary education-II project for MOE and Technical Education and Training Modernization Project for both MOE's and 
MOL's implementation. The revival of Mexico government's enthusiasm was caused by several factors. First, our Regional Vice President's personal meeting with the president of Mexico contributed to the acceleration of Mexican government's borrowing from the Bank for human development investment. Referring to the East Asian Miracle report just published by the Bank (World Bank, 1993), the president of Mexico acknowledged that investment in human development is productive and promised to accelerate borrowing from the Bank for the same purpose.

Second, the government had a good experience with borrowing from the Bank for economic growth through investment in CONALEP's vocational-training programs. Moreover, in 1992, the government obtained a loan for the Labor Ministry's implementation of a large-scale vocational-technical retraining program and labor mobility improvement program. The MOE, which had always been in a competitive position vis-à-vis the Labor Ministry, became eager to play an active role for poverty alleviation and economic growth.

Third, both the government and Bank realized that on the basis of repeated operations for vocational and technical education and training programs of both MOE and MOL, it was time to institute modernized skills education and training systems practiced in many advanced and middle income countries around the world.

The Primary Education Project-II was a follow-on project of the first primary education project approved in 1991. This second project expanded the geographical scope of the assistance. While the primary education-I was piloted in four poorest rural states, this second project included 11 additional states that were covered by the Initial (early childhood) Education Project. This extension of the scope of the project was due partly to MOE's enhanced confidence of the project impact, but also due partly political pressures and demands by other poorer states.

The Modernization of Technical Education and Training Project approved in 1994 was to: establish a national system of competency standards and skills testing and certification; select public and private training institutions for redesigning their training programs into modular courses based on the new competency standards, providing for teaching materials development, instructor 
retraining, and equipment updating; and stimulate enterprises' demand for competency-based training, skill testing and certification.

In advancing these two additional loans, we encountered no resistance from the Mexican authorities or the Bank. While the primary education was justified in the Bank education sector policy on the basis of its superior rate of return, it was justified in Mexico as a compensatory program to meet the basic needs of poverty groups in rural and marginal urban areas. While the training program was justified in the Bank mainly as part of equity and anti-poverty program, it was justified in Mexico as a productive program contributing to the future economic growth, even though it partly addressed the labor market adjustment needs of the relatively poor workers.

In addition, a monumental incidence for the Mexico government's social development policy took place in the same year. WB representatives from the Research Department and the human development sector division of Country Department for Mexico, which was managed by me, were invited to a closed workshop for discussing future policies and programs of the Ministry of Social Development (MOSD) in 1993. We suspected that the final outcome of the workshop would be used in the political platform for the presidential campaign the following year since the incumbent Minister of Social Development had been nominated by the ruling party (PRI) as the official presidential candidate. At the end of the workshop, representatives of the Bank were invited to speak. Since it was a closed workshop, we spoke quite frankly:

"Our Bank colleagues in the agriculture sector division told us that public subsidies are rampant in Mexico, and the annual fertilizer subsidy given to farmers alone was equivalent to about two percent of Mexico's GDP, but in fact the main beneficiaries of the subsidy are relatively richer and larger farm owners. The government may want to streamline the public subsidies, so that they can give them only to the targeted poorer groups. Saved subsidy funds in this way could be given to socially underprivileged and underserved people with a good targeting system. One way of effectively targeting the socially poor groups with good results on the ground would be to give an upfront cash subsidy to parents, who do not send their kids to school, on conditions that they send their kids to primary schools and get their children annual health 
checkups and health education in the nearby health centers. Two years ago, we were helping the Ministry of Health prepare a basic health project for possible Bank financing. However, we were not convinced that a network of health centers to be constructed in poorer villages and rural areas under the project would be well-utilized since, when we visited some rural areas, the utilization of the existing health centers was very low mainly because the potential beneficiaries could not pay the nominal copayment, afford the transportation costs, and were too poor to use the health centers. Also, our educators said that parents in rural areas were too poor to send their kids to school. We wonder why the Mexican government gives public subsidies for goods like fertilizer, but not for education and health services for poor kids."

Our comment was followed by absolute silence. We believed that Mexican officials did not like our idea, or they thought it a non-starter. We thought we had made a blunder and decided to forget this experience.

Sometime later, however, we received a communication from the Ministry of Finance that they were interested in the suggestion that we made at the MOSD workshop and whether the Bank could help them prepare a project for possible Bank financing. Since we did not program such an activity in our budget, we instantly started an application for the Japanese trust fund for project preparation. However, we soon had to stop pursuing such activities since we received news that the presidential candidate was assassinated on a campaign trail. Years after I left the Bank and repatriated to my home country, I visited the Bank to find that the Research Department staff member who attended the MOSD workshop together with us, was working in the human development sector division of the Latin America Regional Office. She told me that she was working on the evaluation of the Progresa (later changed to Oportunidades) project in Mexico, which was a formal name of the project proposal that we suggested at the MOSD workshop. She told me that the idea was revived after the assassination of the presidential candidate and minister of Social Development. The project proposal was financed by the IDB, but the WB was active in monitoring and evaluating the project implementation and impacts. Eventually, the conditional cash transfer project (Oportunidades) in Mexico was financed by the WB in 2009 and 2010 (〈Table 2〉) and was disseminated to many developing 
〈Table 2〉 Mexico: World Bank human development sector lending portfolio (1991-2017)

(unit: \$ million)

\begin{tabular}{|c|c|c|c|c|}
\hline $\begin{array}{l}\text { Year } \\
\text { approved }\end{array}$ & $\begin{array}{l}\text { Project } \\
\text { ID }\end{array}$ & Project name & $\begin{array}{c}\text { Loan } \\
\text { amount }\end{array}$ & $\begin{array}{c}\text { Year } \\
\text { completed }\end{array}$ \\
\hline 2017 & P160309 & Higher Ed & 130 & Cancelled \\
\hline 2014 & P149858 & $\begin{array}{l}\text { Reduce Inequality in Ed Opportunity (Early } \\
\text { Childhood Ed) }\end{array}$ & 150 & 2018 \\
\hline 2014 & P147185 & School Manage w/ Parent Participation III (APL III) & 350 & 2018 \\
\hline 2014 & P147212 & Social Protection System & 350 & 2021 \\
\hline 2013 & P147244 & Upper Sec Ed Dev Policy Loan III & 300 & 2015 \\
\hline 2012 & P126297 & Upper Sec Ed Dev Policy Loan ॥ & 300 & 2013 \\
\hline 2010 & P115347 & School Manage w/ Parent Participation III (APLII) & 220 & 2011 \\
\hline 2010 & P112262 & Upper Sec Ed Dev Policy Loan I & 700 & 2011 \\
\hline 2010 & $\mathrm{P} 122349$ & Additional Fin for Oportunidades (II) & 1,250 & NA \\
\hline 2010 & P101369 & Compensatory Ed (Early Childhood Ed + PrimaryED) & 100 & 2014 \\
\hline 2010 & P116226 & Support to Soc Protect (Health Insurance) & 1,250 & 2013 \\
\hline 2009 & P1150673 & Support to Oportunidades Project & 1,504 & 2013 \\
\hline 2005 & P085593 & Tertiary Ed Assistance (APL I) (Loans to Assistance) & 180 & 2011 \\
\hline 2005 & P088728 & Ed Quality Improv-Result based Grants & 240 & 2009 \\
\hline 2004 & P085851 & Basic Ed Dev III (Adaptable Prj Loan III) & 300 & 2007 \\
\hline 2002 & P057531 & Basic Ed Dev II (Adaptable Prj Loan II) & 300 & 2004 \\
\hline 2001 & P066321 & Basic Health III & 350 & 2009 \\
\hline 1998 & P055061 & Health System Reform (TA) & 25 & 2002 \\
\hline 1998 & P007720 & Health System Reform (Adj) & 700 & 2002 \\
\hline 1998 & P049895 & Higher Ed Financing & 180 & 2006 \\
\hline 1998 & P040199 & Basic Ed Dev I (APL I) (CONAFE) & 150 & 2001 \\
\hline 1995 & P007689 & Basic Health II & 310 & 2002 \\
\hline 1995 & P040462 & Essential Social Service Program & 500 & 1998 \\
\hline 1994 & P034490 & Technical Education and Training Modernization & 265 & 2003 \\
\hline 1994 & P007725 & Primary Education & 412 & 1997 \\
\hline 1992 & P007724 & Labor Market and Productivity Enhancement (MOL) & 174 & 1998 \\
\hline 1992 & P007716 & Initial Education-Early Childhood Ed & 80 & 1998 \\
\hline 1991 & P007690 & Primary Ed & 250 & 1997 \\
\hline 1991 & P007704 & Technical Training Project (MOE/CONALEP) & 152 & 1998 \\
\hline 1990 & P007655 & Basic Health Care & 180 & 1996 \\
\hline
\end{tabular}

Source: The World Bank website (www.worldbank.org).

Note: APL, Applied Program Loan; MOE, Ministry of Education; NA, not applicable. 
countries all over the world, and the Bank research department published an impact evaluation report of many conditional cash transfer projects (World Bank, 2009).

Late in 1994, our department encountered an extraordinary opportunity to play an active role for poverty alleviation in Mexico. The financial crisis that hit Mexico in 1994 forced the government to take a severe retrenchment policy again, just as it was forced to take such a policy as part of the structural adjustment program for getting out of the debt crisis in the late 1980s. In that year, the human development sector of the department in the Bank had already offered loans to the Mexican government for the primary education project-II and technical education and training modernization project, and had just appraised a basic health project-II for a future loan. Through these activities, we learned from our Mexican counterparts that the government was preparing the next year's budget, but that it would be much smaller than the previous year's; most of the cuts would be in the human development sector covering education, health, nutrition, and vocational-technical training, just as had occurred during the late 1980s. In particular, primary education and basic health in the underprivileged and vulnerable areas would suffer the most cuts. Therefore, the Bank discussed with the Mexican government about ways to protect these poorer and vulnerable groups of the population from retrenchment and agreed that Bank financial assistance would save essential social service programs for those groups in the next two to three years that would cost about $\$ 1$ billion. Later, this total program cost was shared with the Inter-American Development Bank, who showed interest in joint financing. The human development sector played a key role in appraising the essential social service programs and presenting the proposal to the Board for approval in a short period of time. It was the first time such a social sector budget support or adjustment type loan was extended in the Bank.

A few years later, in 1998, the primary education project was followed by the first of a series of three large loans to support a slice of the Mexican government's long-term compensatory basic education development program for underserved poorer rural and marginal urban areas (later in 2002 and 2004). We also noted later that the IE project was followed by a compensatory education project to 
strengthen IE and primary education at the community level in underserved states (2010). Stimulated by the Bank-instigated sector study and Bank-financed pilot primary education and IE projects, the Mexican government prepared its own long-term basic education development program, which became a sound and easy basis for a series of Bank's applied program loans (APLs). While the primary education projects covered 15 states selected on the basis of poverty indicators, the basic education APLs covered selected poor and underserved municipalities of all states. We were so happy to enjoy the results of good partnership.

Another initiative taken by our human development sector was supporting a higher education financing project in 1998. The education sector in Latin America was then well known for its serious inequity in financing higher education. The tuition and fees for public higher education were so low and nominal that the system in fact provided public subsidies to students from the relatively well-to-do families, who accounted for a large part of the student body. Young persons from relatively poorer families could not afford higher education since they had to work on a full-time basis to earn their living, and scholarships or student loans were virtually non-existent.

At this time, the education sector managers in the Bank were hotly debating a draft policy paper on the education sector including higher education. The draft proposal put higher education at lower priority than primary and secondary education, and Bank financing for higher education were to be restricted unless scholarship and/or student loan systems were developed or a reasonable user-fees system practiced. Opposing managers mostly working for countries in Africa and Middle East regions argued that their client countries had a keen shortage of young leaders in public and private sectors and a cadre of competent civil servants who needed to be trained by higher education institutions in a relatively short time. Proponent policy makers argued that higher educational institutions in those countries had wasted scarce public resources at the expense of basic and secondary education, which should have enjoyed a higher priority for public investment.

Our department took the position that the Bank should not be just passively closing the door with prerequisites against extending higher education loans; it 
should be taking a more proactive position for investment in higher education by helping the countries establish and strengthen scholarship and student-loan systems. Therefore, in 1998, we helped the government of Mexico establish a student-loan system for private universities that practiced a realistic user-fee system, and strengthen a fledgling student-loan system in one relatively richer state, Sonora. A decade later, this initiative was followed by the government, which transformed the student-loan system to a public assistance system with Bank-financing.

\section{2) Application of the mandates in Central America}

Our education sector effort to operate as a frontrunner in carrying out the Bank poverty alleviation mandate in the 1990s culminated in El Salvador. In the late 1980s, the El Salvador government finally reached a peace agreement with belligerent farmers or revolutionary groups after more than a decade of civil war, and asked for Bank financing of the Community Education (EDUCO) Program for basic education.

During the civil war, the government's education services did not reach rural areas. Therefore, parents in innovative rural communities launched self-help movements to provide school facilities by converting community halls and adding more structures, and organized basic school-management committees, which contracted teachers among community residents and outsiders, monitored and supervised teachers' attendances and performances, rehabilitated and maintained school facilities, and financed other school expenses. When the civil war ceased, the MOE tried to provide traditional basic education services as in urban and marginal areas. However, many rural communities wanted to maintain their parent-centered school-management committees. The MOE decided that maintaining the school-management committees organized by parents and integrating them as an official extension of the MOE administrative network would be more efficient and effective in constructing, rehabilitating, and maintaining school facilities, monitoring teachers' attendances and performances, distributing textbooks and other instructional materials, and even channeling school administration expenses, including teachers' salaries. It also tested students' attendance and learning achievements at the community schools and found that they were equal or better than the government-managed schools in 
other areas not affected by the war. The Bank also quickly assessed students' attendance and learning achievements, using the USAID test data on math and language subjects and confirmed the MOE's earlier findings. Therefore, the Bank financed the community basic education (EDUCO) program, rehabilitating school facilities, training teachers, incorporating teachers into the government compensation and pension systems, distributing instructional materials, and supervising and evaluating teachers' performances, all through the EDUCO committees. This program attracted the interest of many governments both in Latin America and other continents that had problems administering and improving rural basic education programs and systems.

The project was successfully implemented and positively affected the MOE's planning and evaluation program, instruction materials production and distribution system, teachers' supervision and evaluation system, and many other aspects. When James Wolfensohn was elected as the new president of the WB in 1995, he set up a Presidential Award for Excellence in the Results on the Ground to encourage project implementation, outcomes and impacts. The EDUCO project was selected for the second year of the Excellence Award. The Development Economics Department, a research arm of the Bank, took up an in-depth and scientific research of the project design and outcome for wide dissemination outside of the Bank (Jimenez \& Sawada, 1999).

Other countries in Central America also applied for Bank loans to attack poverty in rural areas by expanding and improving basic education. However, our technical department advisers commented that we should not advance such loans since they would likely use the funds as fungible resources. In other words, the governments would be diverting a budget amount equivalent to the Bank loan for basic education to other purposes, and therefore, there would be no additional resources available for basic education. That practice is why those countries did not expand and improve basic education in the past. Moreover, one specific country had a clause in its constitution stipulating that a certain percentage of the MOE annual budget must be allocated to higher education, which is used by higher educational institutions autonomously. Therefore, the advisers argued, besides the fungible use of Bank loan for basic education, the loan would increase higher education budgets in proportion to the Bank loan for basic education, worsening the inequity of higher education financing. 
To prevent this outcome, we decided to ask for a policy statement on a government's strategy for expanding the future basic education budget; the Bank and government would jointly review approved annual budgets for basic education, even though the Bank loan was not a policy-based sector loan. During the project implementation period, we did not observe any loan fungibilty problem.

Ever since the Bank adopted poverty reduction and economic growth recovery with institutionalization as its overriding objectives and strategies for lending operations, the average annual education sector lending amount almost doubled throughout the 1990s, irrespective of the change of WB presidents, and the education sector lending as percent of total Bank lending of all sectors also

〈Table 3〉 Scale of WB and education sector lending: 1963-2020 (unit: \$ million)

\begin{tabular}{|c|c|c|c|c|c|c|c|}
\hline Year & $\begin{array}{c}\text { ED } \\
\text { sector }\end{array}$ & $\begin{array}{c}\text { ALL } \\
\text { sectors }\end{array}$ & $\begin{array}{c}\text { ED } \\
\text { per year }\end{array}$ & $\begin{array}{c}\text { ALL } \\
\text { sectors } \\
\text { year }\end{array}$ & $\begin{array}{l}\text { ED as \% of } \\
\text { all sectors }\end{array}$ & President & Lending goal \\
\hline 1963-68 & 162 & 6,744 & 27 & 1,124 & 2.4 & Woods & $\begin{array}{l}\text { Economic } \\
\text { growth }\end{array}$ \\
\hline 1969-73 & 723 & 12,849 & 145 & 2,570 & 5.6 & McNamara-1 & $\begin{array}{l}\text { Poverty } \\
\text { reduction }\end{array}$ \\
\hline 1974-78 & 1,339 & 32,320 & 268 & 2,570 & 4.1 & McNamara-2 & $\begin{array}{l}\text { Poverty } \\
\text { reduction }\end{array}$ \\
\hline 1979-81 & 1,671 & 33,784 & 557 & 11,261 & 4.9 & McNamara-3 & $\begin{array}{l}\text { Poverty } \\
\text { reduction }\end{array}$ \\
\hline 1982-86 & 3,525 & 73,717 & 705 & 14,743 & 4.8 & Clausen & Debt resolution \\
\hline 1987-89 & 2,195 & 58,262 & 732 & 19,421 & 3.8 & Conable & Debt resolution \\
\hline 1990-91 & 3,738 & 43,387 & 1,869 & 21,694 & 8.6 & Conable & $\begin{array}{l}\text { Poverty } \\
\text { reduction }\end{array}$ \\
\hline 1992-95 & 8,144 & 88,760 & 2,036 & 22,190 & 9.2 & Preston & $\begin{array}{l}\text { Poverty } \\
\text { reduction }\end{array}$ \\
\hline 1996-00 & 8,609 & 115,467 & 1,722 & 23,093 & 7.5 & Wolfensohn-1 & $\begin{array}{l}\text { Poverty } \\
\text { reduction }\end{array}$ \\
\hline 2001-05 & 8,513 & 97,669 & 1,703 & 9,534 & 8.7 & Wolfensohn-2 & MDG \\
\hline 2006 & 1,990 & 23,641 & 1,990 & 23,641 & 8.4 & Wolfowitz & MDG \\
\hline 2007-11 & 14,072 & 198,056 & 2,814 & 39,611 & 7.1 & Zoellick & MDG \\
\hline 2012-16 & 18,002 & 258,326 & 3,600 & 51,665 & 7.0 & Kim & MDG \\
\hline 2017-20 & 16,182 & 192,600 & 4,046 & 48,150 & 8.4 & Malpass & SDG \\
\hline
\end{tabular}

Source: WB Annual Report to Board of Governors.

Note: ED, Education Sector; ALL, All sectors; WB, World Bank; MDGs, Millennium Development Goals; SDGs, Sustainable Development Goals. 
doubled in the 1990s (Table 3). The human development sector was no longer an outsider or a marginal player of the Bank lending operations, but had become a main actor.

\section{FROM EXTERNAL PERSPECTIVE - SINCE 2000}

\section{During the 2000s: MDGs}

Since I left the Bank in late 1998, I have taught at a graduate school in Seoul, Korea, my home country. I was extremely pleased with the news that all aid donors and recipients got together at the UN in 2000 and declared that poverty reduction was the common goal to be pursued by 2015. The Millennium Development Goals (MDGs) were the main guideline for the concerted efforts. I thought that for the first time in aid history, poverty reduction became the main goal and objective in consecutive two decades. In the 1950s, all bilateral and multilateral aid agencies provided assistance for economic rehabilitation and growth recovery of mainly European countries and Japan, and in the 1960s for economic growth of developing countries. In the 1970s, the Bank waged a war against poverty in developing countries, but it could not continue due to the global debt crisis in the 1980s. In the 1990s, the Bank renewed its effort for poverty reduction, and in the new millennium years, the WB sought to carry out this same mandate continuously. Moreover, in the 2000s, all international aid agencies agreed to work for the common goal, and the WB took up the role of monitoring and reporting the progress of the concerted efforts for poverty reduction.

\section{Education Sector Aid for Economic Value}

Looking at the WB education sector operations from outside of the Bank, together with other colleagues sharing the same concerns, was refreshing. Although the WB was officially linked to the UN system, we rarely worked in collaboration with or in consideration of other UN agencies in the past. 
Therefore, when we observed Bank operations from the external perspective, we tended to compare the operations of the WB vis-a-vis other bilateral and multilateral aid agencies, especially UN agencies. The most striking characteristic of the WB was that it worked like a private bank governed by shareholders, extending mainly loans/credits for the economic growth of aid recipients; meanwhile, UN agencies provided mainly grants for humanitarian assistance and operated democratically like the USA Senate, with each state holding equal voting power.

As a result, the Bank education sector policies and reports seemed to justify its education sector operations by economic criteria, most often by rates of return of educational investments, while UN agencies justified their education sector operations by non-economic, legal criteria like human rights. One 2014 WB report entitled Comparable Estimates of Returns to Schooling Around the World exemplifies how education is seen in terms of economic growth by empirically demonstrating that one extra year of schooling boosts earnings by 10 percent on average (Montenegro \& Patrinos, 2014). Together with the Bank, OECD and USAID seemed to focus on the economic value of education. In the 2009 publication of Education at a Glance, an OECD annual report, education is clearly linked to income, thus arguing for the importance of investing in human capital (OECD, 2009). The report asserts that people with advanced degrees earn an average of $\$ 186,000$ dollars more during their lives than those without degrees. The education strategy of USAID likewise was based on the human capital development (quantitative and qualitative) perspective and the critical association between human capital development and economic growth.

\section{Education Sector Aid for Promotion of Human Capability and Human Rights}

UN agencies like UNICEF and United Nations Development Programme (UNDP) have made clear what they aim to achieve through education sector aid. For instance, UNICEF's Strategic Plan (2018-2021) suggests that the organization intends to support the most vulnerable children worldwide to: thrive in their communities, enjoy freedom to choose, have an equitable chance in life, and 
receive inclusive quality education and learning opportunities (UNICEF, 2017). UNDP is an actor in the aid community whose works combine the capability framework as well as the human rights-based perspective. Both UNICEF and UNDP assert education provides individuals with capabilities that enable them to challenge the status quo and bring about a better life and prosperity (Alkire, 2005; Nussbaum, 2003; Robeyns, 2003; Unterhalter, 2003). In 2000, the UNDP helped encourage other aid actors to embrace this framework through its influential publication, Human Rights and Human Development (2000). Many national governments and international donors in the field began to implement strategies in accord with the UNDP's advice and recommendations. Moreover, UNICEF and UNESCO declared their commitment to support for rights-based development programming through networks of nonprofit organizations (NPOs), such as Save the Children and Oxfam (Jordan \& van Tuijl, 2000).

Outsiders like us wondered why two groups of international donors to the education sector of developing countries argue differently, and which group's argument is right. We thought that it had to be judged by their aid effectiveness or outcome on the ground. Our literature review showed that the economic value approach to the education sector investment did result in higher wage and earnings, and thereby economic growth and better income distribution (Asiedu, 2014; Colclough et al., 2010; Lee, 1981; Mincer, 1974; Psacharopoulos, 1985, 1994; Psacharopoulos \& Patrinos, 2004; Tilak, 1989).

In addition, the non-economic value, capability and human rights approach to the education sector investment also had supporting literature. It shows that impacts of investment in education go beyond the enhancement of cognitive knowledge and skills: improvement of hygienic and sanitary practices of children of educational service recipients, decline in their childbirth rates, and increased savings in the next generation, thereby contributing to poverty reduction and prosperity. However, only scant research results were found on the improvement of life skills such as participation in community programs and political activities, promotion of social cohesion, respect for human rights, etc. (Heyneman, 2003; Heyneman \& Lee, 2016).

As such, we got the impression that the capabilities and human rights approach was a more normative argument, although it gave a broader insight. In contrast, 
the economic value approach to the education sector investment gave us a more positive impression with quantitative and concrete measure of economic value or returns to the investment in human resources. However, it also gave us a narrow view of the investment outcomes.

\section{A Hybrid Approach}

We thought the two approaches might be blended to make up for the weaknesses of each approach. What would be the practical differences between the one-sided argument and a blended approach? We could not imagine any specific advantage of one approach over the other. First, when we review our experience with the WB, we did not make a cost-benefit or rate-of-return analysis to justify basic education or IE projects, which aimed to alleviate poverty and provide inclusive quality education in underprivileged rural areas. We simply showed the inequitable public provision of basic education service, which is one of the essential and basic needs of the poverty groups and which would contribute to expanded capabilities throughout their lives. It did not matter whether the recipients of basic education service thought or claimed the service as human rights. They simply appreciated it for satisfying one of their basic needs. At the same time, research literature amply demonstrates the value of the economic value approach, since it would ensure that project outcomes would be evaluated more rigorously upon implementation.

Second, the capability or human rights approach did not discriminate among levels of education. All levels of education, including adult and female education in an informal or community environment, were recognized as human rights and were assumed to equally expand human capabilities and enrich human life. This approach was advantageous for education aid to select different levels of education, depending on diverse situations in developing countries.

However, the economic value approach discriminated education services by level. Over the last several decades, researchers have found evidence of different rates of return for different levels of education. Namely, in developing countries, the returns on education aid were found to be greatest at the primary education level and lower at higher levels of schooling (Psacharopoulos, 1985). This 
finding has largely affected the inception of many global initiatives for basic education, which changed the architecture of educational assistance (NiñoZarazúa, 2016), although this assertion has been challenged by other scholars (Bennell, 1996; Knight et al., 1992; Montenegro \& Patrinos, 2014). The achievement of universal primary education was one of eight MDGs set out by the international aid community in 2000, in line with the 1990 and 2000 World Conference on Education for All (Birchler \& Michaelowa, 2016). However, the WB also emphasized vocational-technical secondary and post-secondary education and engineering higher education, when its mandate was economic growth during the 1960s. The Bank emphasized basic education and non-formal adult education in its lending operations, when its mandate was poverty alleviation during the 1970s, 1990s, and 2000s (Psacharopoulos, 2006; Table 3). Thus, both approaches were equipped to meet the needs of various situations at different times flexibly.

The differences between the two approaches to international aid for education were that the economic approach only focused on the quantifiable, pecuniary, and narrow concepts of educational benefits, while the capability and human rights approach emphasized the broad, non-quantifiable and non-pecuniary concepts of educational benefits. Moreover, the non-economic value approach to educational aid had the disadvantage of weaker evaluations of aid impacts, while the economic approach had more rigorous evaluations of aid impacts, though the impacts were of limited scope. Therefore, the two approaches could be combined or blended.

Each of the two approaches could make up for the disadvantages of other approach. In particular this blended approach would help us meet the SDGs through 2030: The SDGs contain not only poverty alleviation and environmental goals as in MDGs, but also economic growth and equity goals. We concluded that the two approaches together, rather than separately, could meet the challenges of achieving the SDGs better than a single approach alone.

We were, therefore, very pleased to learn of the launch of the Education for All - Fast Track Initiative (FTI) led by the WB, with the developing countries' renewed goal to achieve equitable and quality education for all in 2002. The FTI evolved into the Global Partnership for Education (GPE) in 2016 (Menashy \& 
Dryden-Peterson, 2015; World Bank, 2016). The goals of the GPE offered good evidence of convergence of the two approaches to international aid for basic education.

Historically, the WB has viewed human rights through a strictly political prism, but the title of its publication, "Incorporating Human Rights into Development," was straightforward enough to show the conceptual blending of the two approaches. In the report the analytical perspectives of the funders are largely grounded in the human rights-based dimension, though they maintain their focus on economic contributions as well (OECD \& World Bank, 2013). After all, about 121 million children ages 6-15 were still out of primary and lower secondary school in 2019. Including 138 million youth of upper secondary school age, a total of 258 million children, adolescents and youth are out of school. The challenge is most acute in sub-Saharan Africa, where the net enrolment rate of primary school stood at only 79 per cent in 2018. This means more than 20 percent of primary school age group children are out of school (UNESCO, 2019). In practice, the Bank financing of basic education was justified not by the economic value criterion, but by the basic needs criterion, while the UN system declared basic education a human right mainly because it satisfies the basic needs. Both approaches have sufficient common grounds to join their efforts.

The GPE is a multi-stakeholder partnership and funding platform that aims to strengthen education systems in developing countries in order to dramatically increase the number of children who are in school and learning. It claims that since 2002, there are 77 million more children in school in GPE partner countries and US $\$ 5.3$ billion in grants have been allocated to about 70 partner developing country governments. GPE also encourages partner developing countries to allocate $20 \%$ of their national budget to education, with a significant proportion (45\%) distributed for primary education (GPE, 2019).

\section{LESSONS LEARNED FROM THE WORLD BANK}

We can take out some lessons from our internal and external experiences with the WB education sector lending operations. First, the lending operations of the 
education sector in the Bank were guided principally by the Bank-wide mandates and country-assistance strategies. The education sector policy was subject to these Bank-wide mandates and country development strategy, and could not replace or override them. The education sector policy was formulated mainly on the basis of the philosophies and intrinsic values inherent in the sector, taking into account mainly economic growth of a country and relatively neglecting the poverty alleviation mandate. Basic education projects including early childhood and primary education were not justified by its cost-benefit or rate of return. No such project appraisal reports included any economic analysis. They were justified mainly by their contributions to poverty alleviation mandates and by their satisfying basic needs of the poorer groups in the short and medium terms. Through repeated investment, basic education would contribute to economic growth in the long run.

Second, the Bank should be careful not to impose a ready-made Bank education sector policy to borrowing countries. We had a bitter experience with the diversified or comprehensive secondary education projects in the 1970s and 1980s. A broad set of education policies may be recommended to member countries with different emphasis and pace in divergent countries and regions. The Bank should not sit back after declaring its restrictive education sector policies with preconditions or prerequisites. As a development bank, it should be more proactive in helping the member countries to overcome their constraints with financing and technical assistance, as observed in higher education financing project in Mexico. However, those projects with home-grown programs and designs, like the EDUCO project in El Salvador and the compensatory basic education development program in Mexico, had greater possibilities for successful implementation and sustained impacts.

Third, with the increase in Bank financing of basic education projects, a lot of in-service teacher training programs were financed. It was regarded as a typical investment in human capital, and, therefore, did not require much analytical justification in the Bank. Our technical department advisers did not comment on the teacher training components of the basic education projects, either.

However, proliferation of in-service teacher training program made us un- 
comfortable about the outcome. When we sought technical department advice on the empirical research results outside the Bank in advanced countries, we did not get any reference to reliable empirical evidence. However, on the one hand, we knew that an in-depth study of the basic education in the northeastern states of Brazil showed no significant contribution of in-service teacher training to students' academic achievement (Harbison \& Hanushek, 1992). On the other hand, many years later, one scientific empirical study made in connection with the Korean government's aid program for Laos showed positive effects of a teacher in-service training program on students' academic achievements. Several groups of professors of the only medical school in Laos received one-year fellowships offered by the Korean government and underwent on-the-job inservice training at the Seoul National University Hospital in Korea. After they returned to Laos, they taught the same courses as before. Then, the difference in academic achievements between their students (the experimental group) and other students taught by non-fellowship professors (the control group) was greater than the difference before the fellowship training project between the same courses (Lee \& Kim, 2015). We hope that the Technical Departments (former Central Projects Vice-Presidency) and Independent Evaluation Department of the Bank could take up a rigorous evaluation of in-service teacher training programs, so that the Bank can continue financing them based on scientific evidence.

Fourth, likewise, the Bank should strengthen evaluation studies more flexibly. The Board of Directors said social sectors should also try to conduct economic analysis or cost-benefit analysis as much as possible. In practice, however, it is difficult to apply such analytical techniques during project appraisals. If we tried to apply such analysis, the project processing would be delayed unreasonably or misuse/abuse the analysis without proper framework for the proposed project. In Bank member countries, especially in lower-income countries, necessary time-series data for analysis were unavailable. For example, for rates of return analysis for vocational-technical education and training projects, ideally it is essential to have baseline and future life-time earnings profiles by industry/ occupation, age, education level (vocational/technical secondary graduates separately from general secondary graduates), and years of working experience on 
a regional or national level. However, such earnings profiles are not available even in many advanced countries, let alone developing ones. Therefore, we have to make drastic assumptions to the extent of defying the purpose of the analysis.

Nevertheless, we can build up data through proposed projects to be financed by the WB. The Bank should try to include collection of baseline data on a reasonable scale, such as tracer studies and other labor market studies in the proposed project, especially when the Bank finances similar projects in series; they could be used to justify follow-up projects. Nowadays, the Bank finances not only brick-and-mortar projects, but also software/institution-building components without strong scientific evidence (curriculum reform, textbook development, supervision system reform, distance teacher training, etc.). The WB can function as a knowledge bank and provide persuasive advice to our member countries only when it has sector policies based on scientific evidence tailored to each country or region.

Fifth, a sound education sector analysis can serve as a good basis for the borrowing government and the Bank to identify possible project proposals jointly for future Bank financing. The borrower would have a sense of ownership of the project.

Sixth, the Bank had a unique mechanism for lending operation quality control. On the basis of operation-related research activities and rigorous monitoring and dissemination of academic research conducted outside of the Bank, the technical department (or the old Central Project Vice-Presidency) provided useful advice and comments on the lending operations of the human development sector divisions of Regional Offices. Most of the time, Regional sector divisions found the comments useful and constructive. Sometimes outside NGOs provided harsh criticism, but very often their comments were based on unfamiliarity with the membership-based international organizations and characteristics of largescale development banks. The collegial comments/advice inside the Bank were more insightful and provided democratic checks. This operational quality control mechanism should be reinforced and encouraged in the future.

Finally, when we observe the evolution from the FTI to the GPE, we cannot get rid of our concern that we had with WB's integrated agricultural or rural/ regional development projects during McNamara's era. In our opinion, the pitfall 
of the projects was not in the integrated and coordinated "planning and strategy," but in the integrated and coordinated "execution." The GPE was conceived as multi-stakeholder "partnership and funding platform." We hope that the GPE would not develop beyond its originally conceived boundary. It should remain as a faithful Partnership and Fund, and the Execution would be better done by partners individually.

\section{ACKNOWLEDGEMENTS}

The authors are grateful to Eduardo Velez for helpful comments, and to former colleagues of the human development sector and supervisors of the World Bank, in particular Shahid Husain and Rainer Steckhan, for their support.

\section{REFERENCES}

Alkire, S. (2005). Valuing freedoms: Sen's capability approach and poverty reduction. Oxford, UK: Oxford University Press.

Asiedu, E. (2014). Does foreign aid in education promote economic growth? Evidence from sub-Saharan Africa. Journal of African Development, 16(1), 37-59.

Becker, G. S. (1964). Human capital: A theoretical and empirical analysis, with special reference to education. London, UK: University of Chicago Press.

Bennell, P. (1996). Rates of return to education: Does the conventional pattern prevail in sub-Saharan Africa? World Development, 24(1), 183-199.

Birchler, K., \& Michaelowa, K. (2016). Making aid work for education in developing countries: An analysis of aid effectiveness for primary education coverage and quality. International Journal of Educational Development, 48, 37-52.

Colclough, C., Kingdon, G., \& Patrinos, H. (2010). The changing pattern of wage returns to education and its implications. Development Policy Review, 28(6), 733-747.

Domar, E. D. (1946). Capital expansion, rate of growth, and employment. Econometrica, 14(2), 137-147.

GPE. (2019). Key results. Retrieved from http://www.globalpartnership.org 
Harbison, R. W., \& Hanushek, E. A. (1992). Educational performance of the poor: Lessons from rural Northeast Brazil. Oxford, UK: Oxford University Press.

Harrod, R. F. (1939). An essay in dynamic theory. The Economic Journal, 49(193), $14-33$.

Heyneman, S. P. (2003). The history and problems in the making of education policy at the World Bank 1960-2000. International Journal of Educational Development, 23, 315-337.

Heyneman, S. P., \& Lee, B. (2016). International organizations and the future of education assistance. International Journal of Educational Development, 48, 9-22.

Jimenez, E., \& Sawada, Y. (1999). Do community-managed schools work? An evaluation of El Salvador's EDUCO program. The World Bank Economic Review, 13(3), 415-441.

Jordan, L., \& van Tuijl, P. (2000). Political responsibility in transnational NGO advocacy. World Development, 28(12), 2051-2065.

Knight, J. B., Sabot, R. H., \& Hovey, D. C. (1992). Is the rate of return on primary schooling really 26 per cent? Journal of African Economies, 1(2), 192-205.

Lee, K. W. (1981). Equity and an alternative educational method: A Korean case study. Comparative Education Review, 25(1), 45-63.

Lee, K. W. (1998). An alternative technical education system: A case study of Mexico. International Journal of Educational Development, 18(4), 305-317.

Lee, K. W., \& Kim, T. J. (2015). Real-time impact evaluation of a capacity-building health project in Lao PDR. KDI Journal of Economic Policy, 374), 75-88.

Lipsey, R. G., \& Lancaster, K. (1956). The general theory of second best. The Review of Economic Studies, 24(1), 11-32.

Menashy, F., \& Dryden-Peterson, S. (2015). The Global Partnership for Education's evolving support to fragile and conflict-affected states. International Journal of Educational Development, 44, 82-94.

Mincer, J. (1974). Schooling, experience, and earnings (Human behavior \& social institutions no. 2). New York, NY: National Bureau of Economic Research.

Montenegro, C. E., \& Patrinos, H. A. (2014). Comparable estimates of returns to schooling around the world. Washington, DC: World Bank.

Niño-Zarazúa, M. (2016). Aid, education policy, and development. International 
Journal of Educational Development, 48, 1-8.

Nussbaum, M. (2003). Capabilities as fundamental entitlements: Sen and social justice. Feminist Economics, (2-3), 33-59.

OECD. (2009). Education at a glance 2009: OECD indicators. Paris, France: OECD.

OECD, \& World Bank. (2013). Integrating human rights into development: Donor approaches, experiences and challenges. Paris, France: Organization for Economic Co-operation and Development.

Psacharopoulos, G. (1985). Returns to education: A further international update and implications. Journal of Human Resources, 2044), 583-604.

Psacharopoulos, G. (1994). Returns to investment in education: A global update. World Development, 22(9), 1325-1343.

Psacharopoulos, G. (2006). World Bank policy on education: A personal account. International Journal of Educational Development, 26(3), 329-338.

Psacharopoulos, G., \& Patrinos, H. (2004). Returns to investment in education: A further update. Education Economics, 12(2), 111-134.

Robeyns, I. (2003). Sen's capability approach and gender inequality: Selecting relevant capabilities. Feminist Economics, (2-3), 61-92.

Schultz, T. W. (1961). Investment in human capital. The American Economic Review, 51(1), 1-17.

Tilak, J. B. G. (1989). Education and its relation to economic growth, poverty, and income distribution: Past evidence and further analysis (World Bank Discussion Paper 46). Washington, DC: World Bank.

UNDP. (2000). HDR 2000 - Human rights and human development. New York, NY: Human Development Report Office [HDRO], United Nations Development Programme [UNDP].

UNESCO. (2019). New methodology shows that 258 million children, adolescents and youth are out of school (Fact Sheet No. 56). New York, NY: United Nations Children's Fund.

UNICEF. (2017). Final results framework of the UNICEF Strategic Plan, 2018-2021. New York, NY: United Nations Children's Fund.

Unterhalter, E. (2003). The capabilities approach and gendered education: An examination of South African complexities. Theory and Research in Education, 1(1), 7-22. 
World Bank. (1973). Address to the Board of Governors by Robert S. McNamara. Retrieved from http://documents.worldbank.org/curated/en/9308014683153046 94/Address-to-the-Board-of-Governors-by-Robert-S-McNamara

World Bank (1974), Education sector working paper. Washington, DC: World Bank. World Bank. (1990). Primary education: A World Bank policy paper. Washington, DC: World Bank.

World Bank. (1991). Vocational and technical education and training: A World Bank policy Paper. Washington, DC: Education and Employment Division, World Bank.

World Bank. (1993). The east Asian miracle: Economic growth and public policy. New York, NY: Oxford University Press.

World Bank. (2009). Conditional cash transfers: Reducing present and future poverty. Washington, DC: World Bank.

World Bank. (2016). GPE 2020: Improving learning and equity through stronger education systems - strategic plan 2016-2020. Washington, DC: World Bank Group. 